\title{
Por uma ética em profissão: rumo a uma nova paideia
}

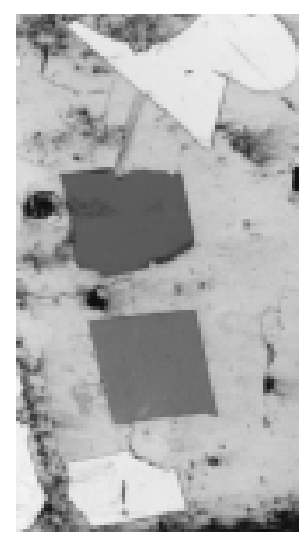

Carlota Boto ${ }^{1}$

BOTO, C. In favor of professional ethics: in search of a new paideia, Interface _ Comunic, Saúde, Educ, v.6, n.10, p.9-26, 2002.

This article discusses the current nature of the concept of paideia, in the light of the interweaving between the original Greek frame of reference and the operative category of what we will call, in this article, "professional ethics". It is a study that intends to formulate guidelines for thinking about the themes of teaching and learning, methodologically, starting from the idea of interdisciplinary studies. This will allow us to recompose the art of pedagogical thinking, avoiding the fragmented specializations of this field, but including in it its chief ethical aspects. We believe that, in this way, it will be possible to establish a new and modern paideia, for contemporary teachers and students in the third millenium.

KEY WORDS: paideia (a Greek work, not translated); education; professional ethics; learning; teaching.

O presente artigo procura discutir a atualidade do conceito de paideia, à luz do entrelaçamento entre o original referente grego e a categoria operatória do que aqui nomeamos uma "ética em profissão". Trata-se de um estudo que busca formular algumas diretrizes para se pensar o tema do ensino e do aprendizado, metodologicamente partindo da acepção de interdisciplinaridade. Assim, poder-se-á, fugindo das fragmentárias especializações do campo, recompor a arte do pensamento pedagógico, incluindo nela seus essenciais aspectos éticos. Desse modo, supomos possível estabelecer para professores e estudantes contemporâneos desse terceiro milênio uma nova e moderna paideia.

PALAVRAS-CHAVE: Paideia; educação; ética profissional; aprendizagem; ensino.

\footnotetext{
1 Professora do Departamento de Ciências da Educação, Faculdade de Ciências e Letras, Universidade Estadual Paulista/Unesp/Campus de Araraquara. <carlotaboto@uol.com.br>
} 
"Não serei o poeta de um mundo caduco

Também não cantarei o mundo futuro

Estou preso à vida e olho meus companheiros

Estão taciturnos, mas nutrem grandes esperanças

Entre eles considero a enorme realidade

O presente é tão grande, não nos afastemos

Não nos afastemos muito ....

..... tempo é minha matéria

O tempo presente,

Os homens presentes,

A vida presente."

(Carlos Drummond de Andrade, Mãos dadas)

O termo paideia, carregado como é da perspectiva de unidade cultural, procura traduzir práticas pedagógicas que, na Grécia Clássica, vinham pela confluência. A paideia era, então, essencialmente o entrelaçamento da formação humana, da idéia do florescimento de uma cultura ampla e tida por geral, dos sentidos da civilização e do referente educativo. Paideia consistia, para o mundo grego, um dado ideal do cultivo e da conduta: instrução, educação, capacidade para aprender, talento para repartir o aprendizado e multiplicá-lo, curiosidade intelectual, desejo de saber e de comungar do saber com o outro. Nada mais próximo da profissão professor (Nóvoa,1991); nada mais condizente com a vocação do educador.

Buscar a paideia era, para os antigos gregos, procurar algo do homem em sua pretendida essência; era construir um discurso que engendrasse a utopia da aretai: conceito grego relativo às virtudes da polis clássica: "bravura, ponderação, justiça e piedade" - quando se tratasse da alma; "saúde, força e beleza", quando se compreendia o físico (Jaeger, 1995, p.534). Da idéia da aretai derivaria o conceito de paideia, que, nos termos de Jaeger, coincidia com uma dada propensão da alma, um certo desenvolvimento do espírito, a ser atingido mediante ideal de formação humana posto no entrecruzamento da "capacidade de assimilação, na boa memória e na ânsia de saber dos homens" (Jaeger, 1995, p. 558). Aretê e paideia eram noções voltadas, ambas, para a mais plena revelação da utopia. Uma utopia construída, sobretudo, com vistas à criação $e$ ao fortalecimento dos laços entre os homens; uma utopia voltada essencialmente para o desenvolvimento de lastros de formação, capazes de conferir a máxima dignidade à condição de homens livres, e por isso homens de ação para a esfera pública.

Como se sabe, Sócrates, em sua procura incessante de um verdadeiro mestre que jamais encontraria, recusa o conceito tradicional da virtude da polis. Andarilho da incerteza, descobre sempre bons especialistas em campos distintos do conhecimento especializado. Nas palavras de Jaeger (1995, p.557), o filósofo conferia

as grandes pretensões dos outros por um conceito novo de paideia, que o faz[ia] duvidar da legitimidade daqueles, mas que leva[va] em 
consideração que nem sequer este conceito novo correspond[ia] ao seu ideal. E através dessa ironia socrática descobre-se a consciência da missão da verdadeira educação e da magnitude de sua dificuldade, da qual o resto do mundo não tem a menor idéia.

Ora, se entendermos com Mannheim (1986, p.229) que "são utópicas todas as idéias situcionalmente transcendentes (não apenas projeções de desejos) que, de alguma forma possuam um efeito de transformação sobre a ordem histórico-social existente", poderíamos situar a perspectiva de uma nova paideia como uma necessária utopia da ação educativa; o ensino como uma marca. Para tal ofício, é preciso o discernimento, a prudência e a humildade que nos oferece o preparo teórico. Para tal ofício, é preciso também uma dada inteligência prática, só com o hábito, com a experiência e com o amadurecimento adquirida: inteligência prática que nos deve possibilitar viver, com a mesma serenidade e firmeza, tanto a glória quanto a adversidade; inteligência prática que nos conduz a aprender com as nossas conquistas, mas também com os erros que invariavelmente cometemos; revelando-nos um percurso reflexivo e sempre em curso, enquanto em curso for a vida em profissão...

Prática essencialmente humana, a educação tende a refletir os paradigmas e o imaginário coletivo da sociedade de onde fala, reproduzindo valores, saberes, práticas, crenças, tradições; mas também vicissitudes, incertezas, perplexidades e contradições que permeiam o tecido social. Ao tornar-se pedagogia, a educação passa a constituir objeto específico de um estudo sobre o ser humano por vir. Compreender a prática educacional supõe, portanto, contemplar um dado vir a ser, admirar-se com ele, tentar compreendê-lo e, finalmente, desvendá-lo. Na utopia da posteridade sempre em construção, o educador projeta sonhos, demarca utopias, aposta desígnios, mesclando desejo de permanência com propostas de transformação.

Se compreendermos a Didática Magna de Comenius como o primeiro grande tratado moderno que, no século XVII, sublinhava o tema da educação, colocando a preocupação educativa no próprio cerne da referência do método, poderemos ler como uma das causas do atraso da instrução o seguinte:

as disciplinas, que, por natureza, são conexas, eram ensinadas sem atender às suas relações mútuas, mas mantendo-as separadas. Por exemplo: àqueles que principiavam a estudar os primeiros elementos das línguas, ensinava-se apenas a ler, deixando-se para alguns meses depois o ensino da escrita (...) Embora todas essas coisas (ler e escrever, palavras e coisas, aprender e ensinar) devam ser feitas tão simultaneamente como, quando se anda, se levantam e se abaixam os pés, quando se conversa, se ouve e se responde, quando se joga a bola, se atira e se recebe, como vimos já atrás, nos seus devidos lugares. (Comênio,1957, p.274-5) 


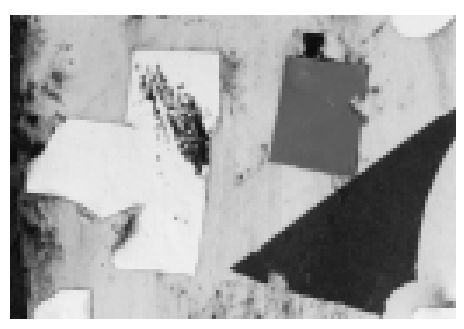

A idéia da interdisciplinaridade, se tomarmos o excerto aqui recordado estaria já, também, posta como uma tentativa moderna de substituição do perdido rumo da paideia grega.

Já não podendo, entretanto, compreender o antigo termo que explicava a antiga Grécia, irrompe a Modernidade educativa, mediante a acepção de uma não nomeada interdisciplinaridade em sua Didática - inventada esta como parâmetro, referência e método, com o fito de ensinar melhor a mais gente. É de se notar que o próprio subtítulo da magna obra de Comenius revela, talvez, a utopia da paideia dos modernos:

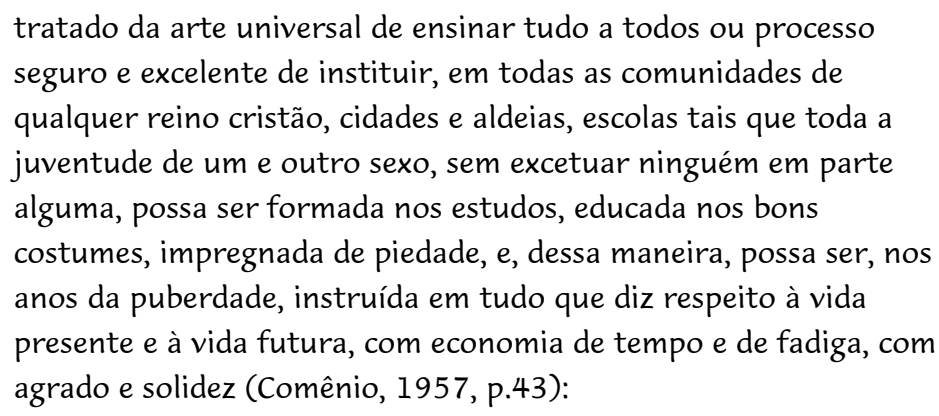

mais uma vez, procurar-se-ia a conjunção entre o bem, o belo e o bom...

Com o paulatino fortalecimento de um moderno sentimento de infância $e$ de família, a escola ganharia, desde o século XVII, novo lugar institucional. Havendo um aumento da procura por parte de populações urbanas $e$ mercantis, organizam-se redes escolares, ainda que, muitas vezes, sob a égide clerical: a família delegara à escola a parcela de sua responsabilidade educativa concernente a uma dada cultura letrada - o ler, o escrever, e o contar. O território da escola é o primeiro espaço seu que a criança tem. A escola é o tempo da juventude. Na escola, as famílias deixam de ter o protagonismo, e a criança passará a lidar com um outro repertório, com outros códigos e signos de saber e de poder. A escola, em certa medida, retrata e recompõe a vida social. Por outro lado, a escola cria e produz essa mesma vida social mediante o descortinar de símbolos e de valores que são, a cada nova geração, recompostos e reatualizados. Se a escola, efetivamente, reflete a vida coletiva, essa mesma sociabilidade poderá ser sempre alterada por decisão do conjunto de seus atores sociais. A escola exerce, pois, no ser humano, o papel de adesão a valores que ele mesmo se impõe. A sociedade escolhe seu repertório e seu script; a escola talvez ensaie a peça... A sociedade e a escola são, portanto, ambas feitas por opções; por escolhas. 
Desde o século XIV, a escola foi progressivamente compreendida como uma instituição para a qual a família delega parte de sua competência educativa. Portanto, espera-se que a escolarização prepare para a vida. Mas o que vem a ser, ao fim e ao cabo, essa preparação para a vida, que tanto se espera da escola?

O espírito do Iluminismo aprofundaria o conceito de ensino e de aprendizado humanista, agora procurando alguma matriz de especialização. No Discurso Preliminar da grande Enciclopédia francesa do século XVIII, os editores Diderot e D'Alembert consagravam as metáforas do labirinto e da árvore para referirem-se ao sistema do entendimento humano. Nesta oscilação, quando a idéia era a da árvore, as ramificações tornavam necessárias as passagens por infinitas encruzilhadas do conhecimento. Quando, por seu turno, o saber era comparado a um labirinto, fazia-se necessário ao espírito proceder a escolhas por trajetos excludentes. O século XVIII convive, nesse pêndulo, entre duas aproximações que se enfrentavam uma à outra: o conhecimento como uma árvore complexa e o conhecimento como um labirinto intrincado. Optar pela metáfora significava, no caso, escolher uma direção, um rumo, um determinado tipo de relação com o conhecimento.

Para retomarmos o texto da Enciclopédia,

o sistema de nossos conhecimentos é composto de diferentes
ramos, vários dos quais têm um mesmo ponto de reunião; e, como
partindo do mesmo ponto, não é possível embrenhar-se ao mesmo
tempo em todas as estradas, é a natureza dos diferentes espíritos
quem determina a escolha. Por isso, é bastante raro que um mesmo
espírito percorra ao mesmo tempo um grande número delas. No
estudo da natureza, os homens esforçaram-se, a princípio, como de
comum acordo, por satisfazer as necessidades mais prementes, mas
quando chegaram aos conhecimentos menos absolutamente
necessários, tiveram de partilhá-los e avançar cada um por seu lado
com passos mais ou menos iguais. Assim, várias ciências foram, por
assim dizer, contemporâneas; mas a ordem histórica dos progressos
do espírito, somente podemos abarcá-las sucessivamente.
(Enciclopédia, 1989, p.49)

Para o Iluminismo, as idéias da instrução, da virtude e da felicidade vinham irremediavelmente atadas. $\mathrm{O}$ ato pedagógico era, conseqüentemente, uma necessária ruptura. A palavra Enciclopédia continha em si a etimologia da paideia, enquanto "círculo de cultura". Há nisso uma dimensão prospectiva de formação humana, de

herança, bagagem de conhecimento adquiridos pelos antigos e de que o indivíduo poderia usar à sua vontade: (...) das disposições a cultivar, dos hábitos a desenvolver, da formação mental... O ser educado aspira a, projeta tornar-se aquilo que é, realizar a sua pessoa enquanto homem. Se, enquanto ser em transformação, pode considerar-se perfeito em cada estádio do seu desenvolvimento, 
continua imperfeito relativamente ao ser perfeitamente desenvolvido que pode realizar-se na idade madura. $\mathrm{O}$ enkyklopaideia é o meio de se tornar plenamente humano, de atualizar o seu prospectivo dever ser humano. (Morin, 1976, p.120)

O pacto de secularização provocado pela Revolução Francesa, os anseios pela fundação de um contrato radicalmente novo, postulado a partir de projetos de igualdade e de liberdade, vislumbrado a partir da primeira derrocada de privilégios nobiliárquicos, referenciariam as grandes bandeiras que passavam a se apresentar como emblemas da educação democrática dos tempos contemporâneos: escola única, universal, leiga, obrigatória e gratuita. A formação da escola de Estado, como política nacional privilegiada entre os séculos XIX e XX, daria substrato histórico a tal ideário. A escola se veria defendida como templo da república, artefato privilegiado para formação de almas em um novo tempo, para um novo homem, de pátrias regeneradas...

A escola do século XIX postula o primado da cidadania, da ciência e da modernidade, como substratos alternativos ao princípio da religiosidade. Contudo, o mesmo século XIX é, também, o tempo das especializações. Consagra-se nele a idéia de que a ordem do saber só pode penetrar sucessivamente no espírito. Firmavam-se e vincavam-se domínios pretensamente autônomos de um conhecimento que se repartia e se separava em espaços de segregação. A separação, cada vez mais evidente, entre distintos e múltiplos territórios do saber, por um lado, estreitava a consciência; por outro, dirigia o olhar. O Foucault de Vigiar e Punir dirá que "a disciplina às vezes exige a cerca, a especificação de um local heterogêneo a todos os outros, fechado em si mesmo" (Foucault, 1991, p.131); embora, freqüentemente os aparelhos disciplinares se valessem de outros princípios, para além da acepção de clausura:

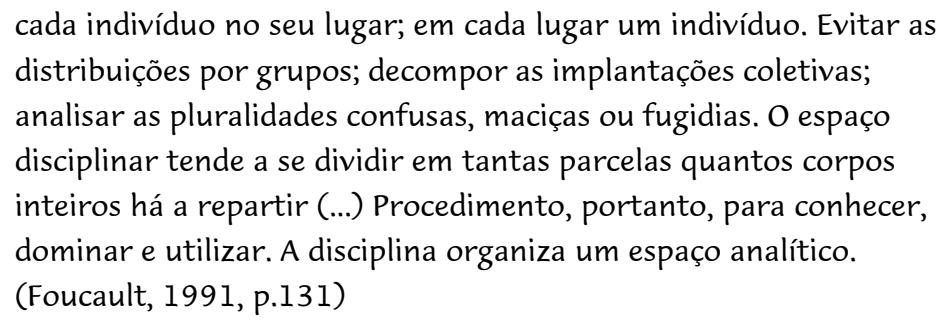

No campo da pedagogia, a própria estruturação da cientificidade do objeto contribuiu para compor o quadro básico do que posteriormente passariam a se chamar "Ciências da Educação". No campo da Medicina, a especialização dos saberes foi uma tendência progressivamente contraposta aos preceitos primeiros da sua origem hipocrática; do médico que, antes da doença, observa por inteiro o ser humano que a contraiu.

$\mathrm{O}$ século $\mathrm{XX}$ percorreu o caminho progressivo e regressivo da especialização. Junto com seu apogeu, percebeu o declínio da unilateralidade dos saberes científicos e dos campos do conhecimento fracionados. Hoje, retoma-se, com bastante nitidez, o projeto multifacetado, transdiciplinar, 
que era dominante no espírito renascentista e no século XVII; o projeto enciclopédico, tão caro à cultura geral requerida pelos ilustrados do século XVIII. Em movimento cíclico, dinâmico, e até mesmo dialético, atualmente compreende-se como necessário e urgente o entretecer de saberes. Campos do conhecimento ultra-contemporâneos não podem, sequer, ser

contemplados por uma única especificidade científica - qualquer que seja ela. As ciências cognitivas; o projeto genoma; as ciências da computação; os estudos ecológicos - pertencem a qual área particular do saber humano?

Será, possivelmente, um novo modelo de interlocução transdisciplinar capaz de fazer dialogar inúmeros cenários do conhecimento humano pesquisado e produzido em diferentes domínios da ciência - que conquistará a curiosidade intelectual, o desejo de saber dos cientistas e da universidade de maneira geral. Academicamente, cabe propugnar, nos dias que correm, um novo encontro humanístico com o conhecimento para a descoberta de novo paradigma. Há, contudo, para tanto, cercas a serem transpostas. A primeira delas é o restrito e unilateral território das especialidades. $\mathrm{O}$ conhecimento de uma única área do saber torna duvidoso o próprio domínio daquela área particular que se pretende saber. Compete ao profissional do futuro uma agenda exposta justamente perante o neologismo recém-criado: "interface"... Tomando a liberdade de nos valermos da apresentação do número 1 desta revista Interface de matriz transdisciplinar, retomaríamos o seguinte texto; recompondo, obviamente seu contexto de produção e de circulação:

\footnotetext{
No atual momento de transição e crise, em que o pensamento científico liberta-se das certezas, Interface nasce comprometida com o diálogo, propondo um espaço plural que assegure a comunicação entre o que é diverso, sem perder a perspectiva de um projeto de organização, construção e difusão do conhecimento. Surge como um objeto-fronteira, socializando estudos, debates e experiências concretas de diferentes perspectivas.... do conhecimento como construção de relações e apreensão de significados, numa rede heterogênea, acêntrica...propondo-nos a leveza, a rapidez, a exatidão, a visibilidade, a multiplicidade e a consistência, como valores universais a desafiar as formas de comunicação do próximo milênio, ao mesmo tempo em que reforça a idéia de rede e do conhecimento como enciclopédia aberta e acena para a necessidade de uma outra forma de conhecimento, esta marcada por uma racionalidade mais plural, por um discurso mais literário e, sobretudo, pela certeza de que não estamos pessoalmente separados daquilo que estudamos. (Interface, v.1, n.1, p.5)
}

Os tempos deslocaram e recriaram as fronteiras: fronteiras históricas, que indagam o repertório dos processos de colonização; fronteiras geo-políticas em tempos de crise das clássicas demarcações herdadas do Estado Nacional; fronteiras de um tempo no qual as anteriores convicções e os paradigmas universalizantes que marcaram a Modernidade já não atendem às inquietações intelectuais que nos são contemporâneas. Além disso, a própria 
relação do homem com o conhecimento tem sinalizado para tecnologias intelectuais inovadoras, que - se, em alguma medida, ampliam o potencial de uma cultura global - deverão alterar substancialmente os padrões educativos e, sem dúvida alguma, as práticas de leitura da sociedade futura.

Trazer para o debate educacional a intersecção transdisciplinar do conhecimento supõe a procura daquilo que jorge Nagle (1976) chamava há algum tempo de pluridimensionalidade. As fronteiras epistemológicas entre o território da história da cultura, as formas de educação contemporâneas $e$ os processos de compreensão do mundo deslocam-se, repartindo, talvez, sob novos parâmetros, os modos de conhecer, de produzir e de reproduzir as relações culturais. As ciências cognitivas - entre a herança da Antropologia, o legado da Sociologia e os avanços da Biologia - certamente têm algo novo a dizer para psicólogos e educadores. A escolarização - na era da informática, da cultura digital e midiática - passa a disputar, com os antigos, os novos, $e$ os ultra-novos instrumentos, o lugar de multiplicadora e transformadora da cultura do impresso. A educação da atualidade, na interlocução com sua época, debruça-se sobre impasses do presente e expectativas de uma escola do futuro. Por sua vez, o campo da cultura abandona alguma pretensão totalizadora da Modernidade, sem, contudo, necessariamente abrir mão de postulados, ainda, tidos por universalmente humanos. Há sentido, sob tal enfoque, a preservação de conteúdos clássicos, ou de um fundo de cultura comum. Há sentido, também, no ato de se recolocar o tema da igualdade na sinalização das diferenças.

Trabalhar a educação é ter por objeto as gerações mais jovens; é palmilhar por elas o futuro; é falar de perto ao coração da utopia.

Referenciada pelo futuro, a prospecção da utopia situa-se na tênue fronteira entre o sonho e o projeto. Aceitar como compromisso o desafio de ser metodologicamente utópico requer do profissional, por vezes, ousadia no enfrentamento das próprias organizações, com o objetivo de despertar novas consciências e recriar, no dia-a-dia, as mesmas organizações, com alicerces recriados; mais amplos, mais integradores. Ameaça ao presente e antecipação do inédito, a utopia emerge nos sonhos de liberdade, nos anseios por igualdade, na luta por uma sociedade, enfim, mais fraterna ( $e$, por tal razão, talvez, mais terna). Pela atmosfera da possibilidade da utopia, o futuro surge-nos sempre em aberto, em suas indeterminações $e$ interrogações, mas em aberto; portanto, o futuro poderá sempre ser diferente. Haverá utopia onde e quando houver história; onde e quando em algum futuro, sempre impreciso, pudermos escutar os brejeiros ruídos do acaso; haverá utopia onde houver sonho de mudança - onde a capacidade de se admirar se fizer acompanhar da inconsolável coragem de se indignar perante a injustiça e, contra ela, propor transformações; haverá utopia onde existir juventude - se as gerações mais jovens se dispuserem a acreditar que o direito à diferença só ganha legitimidade quando acoplado ao requisito da igualdade.

Se, no diálogo sempre inquieto entre mestre e discípulo, a verdade se constrói necessariamente por um "encontro a dois", que terá como território o mundo da cultura (Gusdorf, 1970), existe uma condição essencial para a existência do ato educativo: a decisão de ensinar. Não nos 
convencendo jamais da veracidade de nossas palavras, não podemos, por tal razão, deixar de dizê-las. Isso conduz a que a aula seja, todos os dias, um enlace entre a mais atrevida invenção $e$ a mais cômoda repetição: representação do inédito e reedição do antigo. A dúvida que angustia, todos os dias, o educador compromissado com a busca de sua própria paideia expressa-se na aparente banalidade de uma questão recorrente: o que vou dizer hoje a meus alunos?
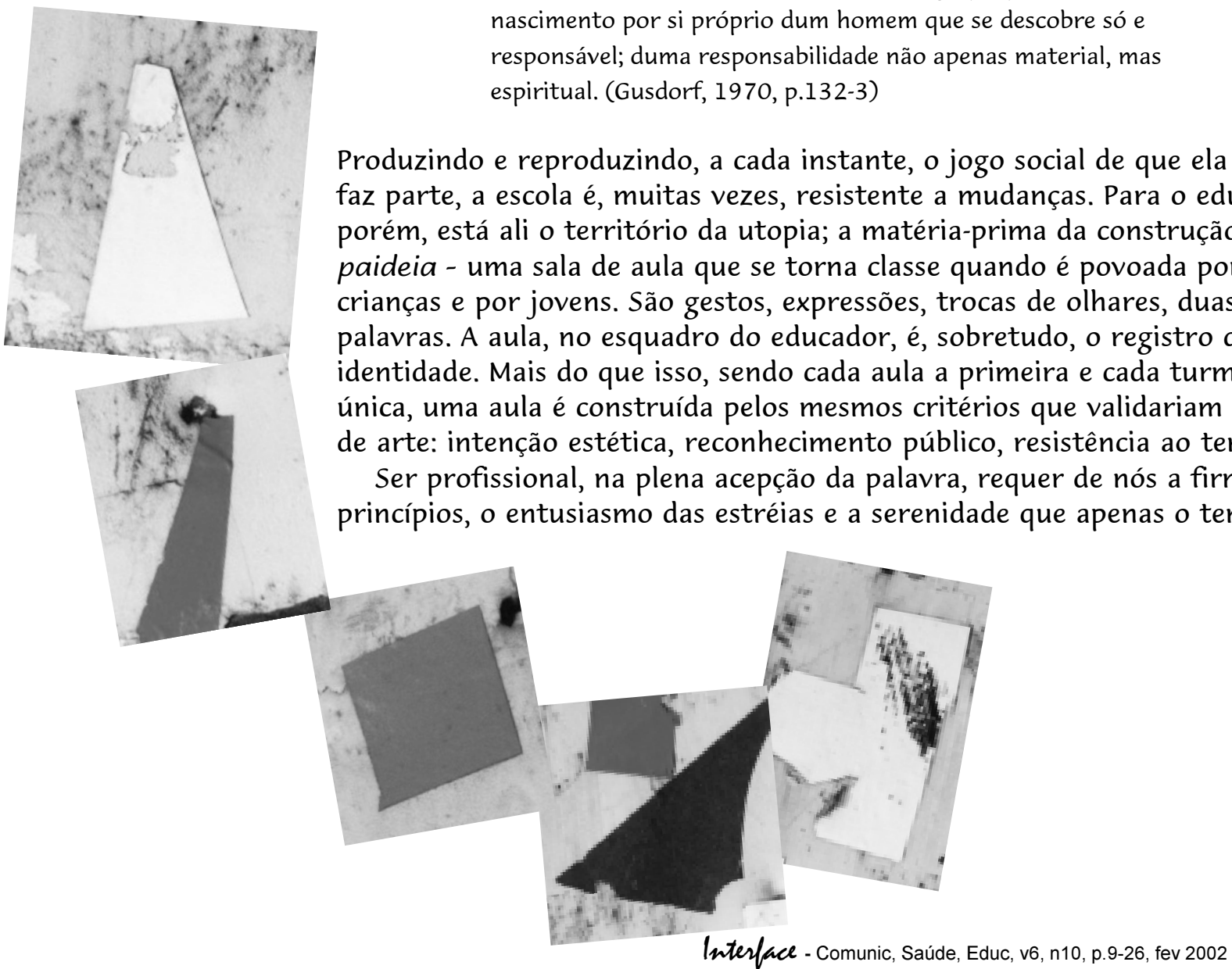
hábito estão aptos a conferir. Há de se buscar, na vida em magistério, habilidade para lidar com o outro e com o diferente; ser professor sugere, ainda, que sejamos capazes de confrontar cada etapa de nossa vida profissional com o transcurso já efetuado e optar por caminhos que nem sempre serão os mais fáceis; mas se colocam, dentre todos os que, em cada situação, se apresentam, como os mais éticos, os mais corretos, os mais valorosos.

Ser profissional convida-nos, finalmente, a tomar a metáfora da colegialidade como nosso campo e nosso projeto. Segundo António Nóvoa (1991), somente a prática do convívio profissional, da partilha, da troca e da sensibilidade para com os colegas possibilita o sucesso. Eu recebo o que meu colega me acrescenta; eu ofereço aquilo de que meu colega pode ser acrescido. Ao agir assim, ambos crescemos, ambos nos empenhamos em uma prática salutar e cidadã de convívio público, ambos transformamos o quotidiano da escola em um exercício de formação continuada. Para viver a colegialidade como proposta profissional coletiva, deve-se, contudo, favorecer o diálogo - e muito particularmente o diálogo entre professor $e$ alunos. Esse diálogo atravessa as rotinas, as práticas, os usos e costumes da ação educativa.

Os adultos têm o que ensinar aos jovens, como ordenar seus sonhos, dominar seus sonhos (o que não significa, de modo algum, renunciar a eles), ir além de sua história pessoal e das tentações do narcisismo, esforçando-se para ser objetivos. Existe como que uma efervescência na juventude, que pode se perder e cair no ceticismo. A influência adulta pode contribuir para transformá-la em impulso autoconsciente, em tarefas possíveis e mesmo necessárias, consideradas certas condições históricas. Mas é com a juventude que se conta para insuflar como que uma febre criadora. É a capacidade de amar o mundo, de animá-lo, contra tudo e contra todos, que os jovens têm a transmitir aos adultos. 'Quando a juventude esfria, o resto do mundo treme'. É pela influência, pela ação dos jovens que os mais velhos têm uma chance de escapar a um dos mais graves riscos que os ameaça: a indiferença. Os adultos 'têm necessidade de provar a si mesmos, admirando de novo o que eles admiravam outrora, que não estão decadentes. ... Encontrar enfim a solução do problema que a infância lançou: 'o que é uma grande vida senão um pensamento de juventude executado pela idade madura?' A juventude sonha e muitas vezes sonha certo, mas na falta de meios e instrumentos eficazes, permanece em estado de sonho. A vida adulta, para que o imaginado assuma formas efetivas, torna-se criação, construção, cultura, conservando-se os gostos da criança que brinca, do jovem que deseja. (Snyders, 1996, p.62-3)

Acreditando ser possível ajudar a juventude a se conhecer para, com ela, reaprender o dom de amar, Snyders ressalta como alicerce da ação pedagógica a recuperação da capacidade de se admirar; tão presente entre 
as novas gerações. O entusiasmo de um particular modo de olhar, de observar e de mirar pode traduzir-se, no ato da instrução, em uma oportunidade de fascínio e encanto propiciado pelo contato com o saber clássico. Aprender a conhecer seria, assim, um ato de emancipação intelectual, sem dúvida; mas também um ato de alegria - de entusiasmo pela descoberta e o desejo de mergulhar na descoberta... Metaforicamente, poderíamos dizer, tomando de empréstimo as palavras de Jorge Larrosa (1998, p.175):

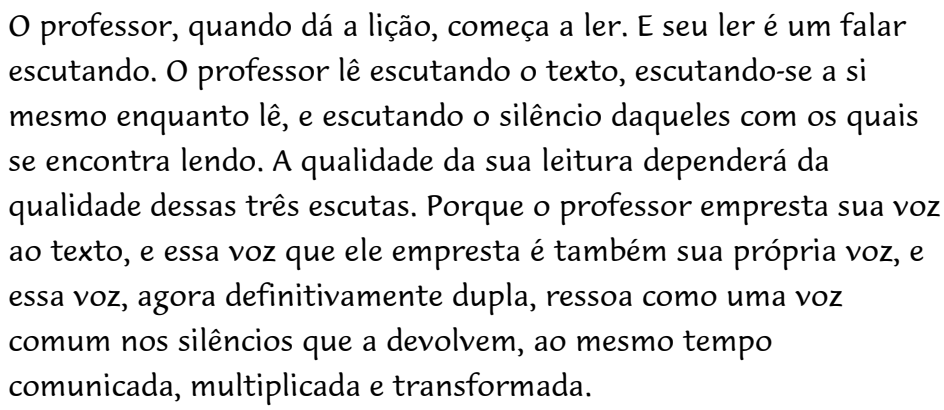

O bom professor pode ser, portanto, compreendido como aquele que se revela a seus alunos por transmitir conhecimentos: chaves culturais herdadas e preservadas como saberes socialmente cultivados. Mas o bom professor, que revela o conhecimento, e o transforma em sabedoria, faz isso por palavras e pelo hábito; pela coerência entre aquilo que diz e as maneiras de atuar em público. O bom professor conjuga habilidades e competências técnicas, acadêmicas, interpessoais, institucionais, com o requisito imprescindível da busca sempre presente de uma vida digna, pautada por procedimentos de justiça para com o semelhante e de cuidado para quem está próximo.

A vida justa é sempre e invariavelmente a vida com os outros; mas é também uma arte, a ser quotidianamente palmilhada: o domínio progressivo dos códigos éticos da conduta pública; dos modos cotidianos de se revelar para os outros. Para tanto, é preciso lisura; mas é fundamental também o sentido de auto-preservação. Dizia Aristóteles que, em geral, o bem está no justo meio entre dois extremos: fazer o bem é tomar por pressuposto a igualdade, sem deixar, contudo, naufragar a tolerância para com as outras pessoas, quando, tantas vezes, desejamos encontrar em quem está ao nosso lado um nosso idêntico; $e$, ao fazer isso, perdemos o que há de rico e de singular nas diversas identidades.

Seguir o justo-meio da ética é ter na liberdade um caro emblema, mas é também agregar nessa liberdade o valor da responsabilidade, que, por definição, precisa acompanhar o território dos direitos. De qualquer modo, a ação ética é uma prática, um hábito, que ninguém tem no ponto de partida, mas que deve ser percorrido todos os dias, quando pretendemos tornar nossa existência profissional uma narração dotada de sentido (Camps, 1995); quando projetamos nossa vida recolhendo do passado significados $e$ procurando pistas para projetar adiante nossas utopias. A capacidade para elaborar utopias viáveis é requisito para o acontecer das transformações. É 
pela ética que poderemos fazer isso - e ética só é para valer no exercício continuado e refletido de nossa alma em direção ao bem comum. Bem comum, por sua vez, é valor compartilhado. De acordo com Victoria Camps, o ser humano reconhece a si próprio como um "ser intersubjetivo, que se sabe comunitário, dialógico, submetido a regras, incapaz de conhecer ou de justificar qualquer coisa por si só. E que, na intersubjetividade, o diálogo e o submeter-se a regras contam, todavia, com um ideal de liberdade" (Camps, 1995, p.60). Assim sendo, a liberdade da vontade humana seria diretriz maior da ação ética, a qual, por sua vez, pauta-se pela perfeita identidade entre meios e fins da ação. Toda e qualquer ação interpessoal é pública; revelando-se, enquanto tal, expressivo e propício cenário para o exercício de um justo agir cotidiano. Tal disposição de espírito e prática consciente proporciona enriquecimento espiritual $e$ favorece a criação/re-criação do homem enquanto ser para si.

Sentimo-nos educadores quando nossos alunos nos contam que algo do que fizemos foi para eles importante; eles que são, no limite, o sinal de nossa voz, ampliada e ressoada; que nos darão continuidade e que irão além de nós. É aqui que eu gostaria de apresentar uma categoria operatória para a reflexão a propósito de uma nova paideia em profissão: proponho uma ética da amizade. Eu explico: meu desejo, ao formar futuros profissionais da educação, deriva de um sonho que, nesta arte, me acompanha: a possibilidade de nós, educadores, aprendermos a nos disponibilizar afetiva $e$ emocionalmente para encontrar, subitamente, no colega e em nosso aluno, um amigo; o encontro desse amigo acontecendo pela força do acaso consentido, da abertura para receber e para doar, mediante uma atitude desprendida de companheirismo, de troca e de intercâmbio: coleguismo. $\mathrm{Na}$ vida em profissão, temos colegas. Se exercitarmos, contudo, nossa habilidade para a colegialidade, adquiriremos, em nosso universo de trabalho, amigos; $e$ teremos a felicidade de obter, no território da escolha profissional, um convívio semelhante ao que experimentamos com o amigo que, espontaneamente, tivemos a oportunidade de escolher.

Francesco Alberoni - em belíssimo ensaio sobre o tema - define a amizade, não pelo tempo corrido ou pela convivência cotidiana. A amizade ocorre quando nos reconhecemos no outro; pela intensidade dos momentos que vivemos juntos -sejam estes freqüentes ou não. Assim, o código da relação de amizade constituiria exatamente "uma filigrana de encontros" (Alberoni, 1993, p.14); nos quais despertam sentidos, firmam-se identidades, marcamse gestos de mútua admiração. A amizade, regida pelo signo da liberdade, costuma, ainda, no parecer do autor, aproximar-nos da felicidade. $\mathrm{O}$ companheirismo proporcionado pelo encontro do amigo traz, invariavelmente, situações privilegiadas de fruição; de prazer. Há critérios morais que envolvem a escolha do amigo. Por isso, em
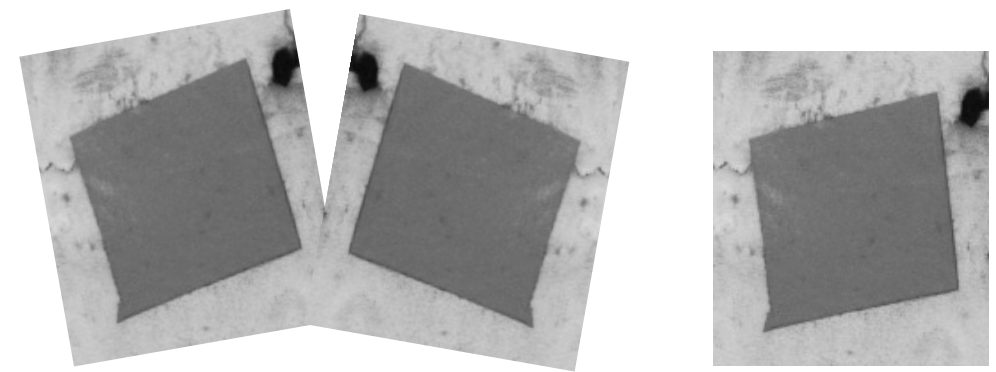
geral, amigo é quem está ao seu lado - como se houvesse um pacto de estar ao lado; um pacto de se fazer justiça; um pacto até de 
se mostrar para o outro possíveis equívocos e desvios de rota; um pacto, porém, receptivo para relevar pequenas faltas; equacionar situações malresolvidas, e até - por que não? - perdoar. Diferente do amor, nesse sentido, o sentimento da amizade "escolhe seus objetivos com critérios morais e se comporta moralmente em relação a eles" (Alberoni, 1993, p.29).

Evidentemente, quando tratamos de profissionalismo, não estamos na mesma órbita que seguimos quando se trata de amigos. Ainda recorrendo a Alberoni, o dever ético pode ser entendido na perspectiva de um "como se" do amor (Alberoni, 1992, p.53). Na ausência do sentimento, poder-se-ia sugerir uma ética profissional (parafraseando o referido autor) em termos de um "como se" da amizade. É possível viver em profissão, por atos, por gestos e por intenções com uma disposição interior, uma atitude que, por decisão própria, converge com a ação que se tem para com os amigos. No caso, tal profissionalismo seria dever: mas um dever, "como se fosse" amizade (Alberoni, 1992). Tal propósito supõe agir institucionalmente 'como se' nossos colegas fossem todos nossos amigos. Isto posto, será possível organizar a vida coletiva, da profissão que escolhemos, mediante modos de agir análogos à experiência da amizade. Para tanto, seria necessário o estabelecimento de uma pré-confiança básica: para que se possa reconhecer no outro a convergência; $e$ para que se possa trabalhar este outro suas possíveis dissonâncias - exatamente como costumamos fazer com aquele amigo que não queremos perder. Embora sempre solicite uma atenção específica para si, o verdadeiro amigo é - segundo Alberoni - alguém que raramente pede favores; porque sabe que, pedindo, receberá; $e$, paradoxalmente, ao receber certos favores, podemos romper com os próprios preceitos éticos que nortearam essa sempre "arte do encontro", situada em mares de "desencontros pela vida" - de que falava Vinícius. $\mathrm{O}$ grande risco da amizade - companheirismo, alegria partilhada, cumplicidade - reside na tentação de tal energia poder se transformar em particularismo excludente. Assim, ainda vale, como parâmetro e norma, mesmo amigos, o ponto regulador da universalidade - e, portanto, imparcialidade, da ação ética. Assim, recomenda-se a cautela, justiça e eqüidade no trato interpessoal:

Ao meu verdadeiro amigo não posso pedir que aja comigo violando a regra da imparcialidade. Se for médico, que se descuide dos demais doentes, se é juiz, que me favoreça. Se ele o fizesse, seria imoral e, portanto, merecedor de desestima geral. Assim, sendo meu amigo, não posso desejar seu mal...Hoje, quando a sociedade está estabelecida sobre regras universalistas, a amizade deve, em primeiro lugar, respeitar o universalismo e a imparcialidade. A amizade aceita as virtudes assim como a sociedade as dá e as respeita rigorosamente. Não as cria, mas é delas a mais respeitosa cumpridora e a mais ciosa guardiã. (Alberoni, 1993, p.40)

Sob tal enfoque, a vida profissional não garantirá, pela ética, o êxito ou o bem-estar - sucesso e fracasso são companheiros tão provisórios quanto impostores. Mas estaria, talvez, engendrado o ponto de partida para um profissionalismo refletido; ou seja, um ato de vontade a ser trabalhado $e$ 
ajuizado pelo intelecto. Quantos de nós meditamos sobre o profissionalismo antes de entrar na profissão escolhida? Como pensar os dilemas éticos da ação colegiada - interpares? Quais os deveres e dilemas éticos em relações hierárquicas? Não estariam grande parte de nossos problemas de convivência institucional em tais dificuldades?

Há um (em alguma medida) confortável silêncio ou esquecimento quando se trata de refletir - de maneira organizada, metódica e planejada - acerca da ética em nossa formação. Reiteramos, por vezes, tal lacuna na formação de nossos discípulos/alunos. Contudo, todos sabemos que ética é hábito; $e$, como tal, deve ser praticada na vida cotidiana; deve ser tema corrente e indagação verdadeira. Há prática de ensino e de aprendizado de ética? Nas universidades, por vezes, professores que não convivem bem entre si talvez prefiram não discutir, com a necessária constância, projetos coletivos pensados para formar o cidadão ético - que todos desejamos para o futuro de nossos alunos. Mas, como não sabemos fazer, talvez não consigamos ensinar. Preferimos - quem sabe - não conversar sobre isso; para não escancararmos nossas dificuldades interpessoais. Agindo desse modo, mutilamos, à partida, não apenas a formação dos profissionais do futuro, mas os nossos próprios projetos de futuro. Não sabemos viver juntos, sem nos separarmos sistematicamente. Os currículos sofrem essa fratura. Os profissionais que formamos atendem ao mercado; atendem, alguns deles, às exigências acadêmicas. Mas estarão à altura de sonhar com um mundo transformado? Um mundo mais justo, mais bem distribuído, mais companheiro e mais fraterno? Para além do sonho sabem verificar a tênue, mas fundamental, interface entre utopias e realizações?

Formar as gerações mais jovens, em alguma medida, tem por suposto o firmamento social de novas estréias profissionais. Os inícios são habitualmente caracterizados pelo signo do desafio, da ansiedade, da criativa insegurança, da utopia... e do glamour. Mas os inícios são indiscutivelmente provisórios. Posteriormente, compete ao profissional - como já destacava Victoria Camps (1995) - conferir um sentido, dotado necessariamente de valor, à própria vida. Estaremos, nós, docentes da universidade pública, neste ano um do terceiro milênio, de fato, atentando para que nossos alunos se preparem para dotar de sentidos uma posterior narração de suas vidas profissionais? Tais significados devem ser antecipados no pensamento cuidadoso sobre a vida em profissão: significados meticulosa $e$ laboriosamente construídos, com observação de realidades e com prospeções de utopias (por que não?); com continuidades, permanências, transições e rupturas - todas elas essenciais para o amadurecimento de uma vida; com coragem e ousadia amparadas por humildade e cautela; com a necessária prudência e o imprescindível entusiasmo de quem não abdica de se indignar
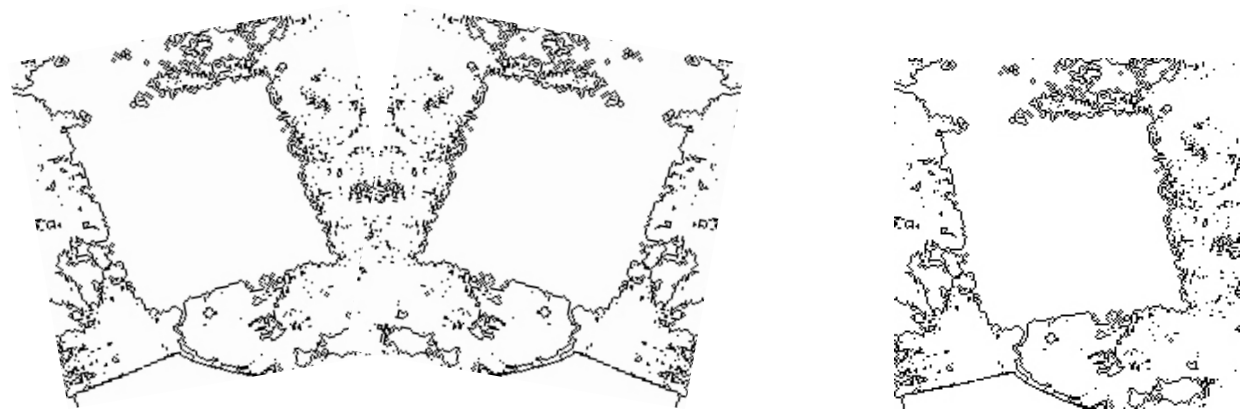

22

Interface - Comunic, Saúde, Educ, v6, n10, p.9-26, fev 2002 
e de sonhar; com o distanciamento científico em uma mão e o engajamento militante na outra - para sempre burilar os modos de ver; as decisões $e$ rotas; os modos de agir.

O bem compartilhado em educação reside, essencialmente, na interação coletiva e colegiada das práticas; das experiências; dos projetos. E o melhor paradigma para se falar em repartir das pequenas felicidades cotidianas ainda é - a meu ver - a experiência do mais livre, mais autônomo e mais sereno dos sentimentos: a experiência da amizade. Para o amigo, eu confesso os códigos, reparto as 'dicas', entrego os 'segredos' do êxito obtido - na boa aula que dei, na pesquisa que efetuei, no texto que produzi, nos autores que li. Ele faz o mesmo comigo. Em tal interação, ambos crescemos. Para meu colega: eu conto aquela aula que deu certo? Eu digo quais os modos de trabalho que proporcionaram resultado positivo? Ou guardo apenas para mim; com o objetivo de que meus segredos docentes não sejam copiados? Na segunda hipótese, eu perco - junto com colegas, alunos e universidade. A esperança de maior qualidade no ensino convida-nos, talvez, para a experiência da generosidade recíproca - porque são recíprocas as relações interpessoais.

Tal operação metodológica no agir profissional não elimina, de modo algum, a competitividade. Continuarei a atuar pelo coletivo, com a manutenção das esferas de ação íntimas. Ao depositar no colega a confiança que eu entregaria a um amigo, estou à espera de que ele aja comigo pela mesma tecla. A reciprocidade, assim, torna-se esperança - mútua e universal - de aprimoramento; daquilo que os iluministas do século XVIII nomeavam 'perfectibilidade'... Estarei, acima de tudo, construindo a possibilidade de uma ética em profissão referenciada pelo código comum e universal do sentido da amizade: agir, perante o mundo, como se tivéssemos diante de nós um verdadeiro e leal amigo. E a amizade, como se viu, contempla a noção de pertença espontânea: foi porque assim eu quis que eu escolhi este (e não qualquer outro) círculo profissional. Há de se estabelecer, pois, no circuito do ensino e da pesquisa acadêmica, compromissos e pactos de respeito e de tolerância para com o pensamento divergente - o que, no limite, nada mais é do que dever e garantia da vida democrática. Nesse sentido, podemos acrescentar, à justiça e à solidariedade (Camps, 1996), o valor da esperança.

A esperança no ato educativo é, por sua vez, sobretudo, uma aposta. $\mathrm{Na}$ constelação social, podemos atuar ingenuamente na educação, convictos de que é justa a estrutura que rege o campo da política e da economia; podemos, na outra margem, recusar a ação educativa, acusando-a de conduzir necessariamente à reprodução da mesma ordem estabelecida, aqui considerada injusta, ilegítima; e podemos, como uma terceira via, naquele lugar intermediário que alguém já chamou de ação sensata (Hameline, 1991), ultrapassar, com moderação, equilíbrio e cálculo, esses dois caminhos anteriores. Trata-se, na escolha, de uma aposta pedagógica e ética, fundada sobre a crença $e$ a esperança na igualdade do gênero humano. Educar é apostar: no futuro, no gênero humano, nas gerações mais jovens. Educar é apostar também no compromisso com a edificação de uma sociedade mais justa, mais generosa e mais fraterna. Educar é apostar na 
capacidade de o homem transformar-se; e transformando a si, transformar a sua prática. Só essa aposta pode vivificar no educador a utopia e o contraponto do tempo, que leva muito mais do que parece trazer. E assim, chegamos ao final de um novo começo, mediante o qual se pode conceber -entre apostas $e$ certezas - o educador como

um navegador que estuda sua rota por todos os meios científicos de que dispõe, mas que, antes da partida, escolheu livremente a direção por tomar e nela apostou. Navegar implica obediência à escolha apostada: obediência ao peso dos meios para realizar o percurso e escolha pessoal da rota. Do mesmo modo, o educador deve apreender com lucidez os meios de sua ação e apostar livremente no rosto que deseja ver no homem futuro. (...) Educo, tanto porque acredito ter razão para fazê-lo quanto porque tenho vontade de fazê-lo em nome dos valores em que aposto. Só posso educar porque acredito nisso. (Hannoun, 1998, p.163)

Pensar a política educativa mundial nestes sinuosos tempos de globalização requer, invariavelmente, o entrelaçamento de variados aspectos, para abarcar tangentes entre o domínio tido por global, o plano local e o território nacional. Mas a história não nos entrega desafios que não sejamos capazes de enfrentar; como já dizia Marx. Para tanto, é preciso que haja temas e perspectivas a serem pensados, a serem debatidos e a serem, fundamentalmente, compartilhados. Daí advém o convite para tornar da educação nossa aposta e nossa paideia: fluir e partilhar o saber investigado; por uma ética da 'amizade em profissão'. Finalmente, à luz de tal projeto, pelo coletivo, pelo diálogo, pela ressonância e, por vezes, até, pela dissonância, supomos a ocorrência da produção e da ampliação do conhecimento desejado. São pequenos, fugazes, $e$, tantas vezes, fugidios, os instantes de felicidade nos quais nos reconhecemos mestres. Tais oportunidades de encontro poderiam se tornar o mais elevado sentido da palavra aula: roteiro, bússola, sempre indeterminada e incerta, sempre sujeita a se deparar com o inesperado, com o imprevisto com o súbito improviso. A aula é - ainda e antes de tudo - o maior registro da existência do mestre, a prova de suas pegadas intelectuais; o legado do que deixaremos para os que vierem depois de nós - como profissionais e como seres humanos. A nova paideia - necessariamente transdisciplinar - partirá, sob tal enfoque, da partilhada curiosidade intelectual: o desejo de saber e o desafio de aprender com os que vieram antes, com as outras matérias e com os que estão ao lado...

$E$ se alguém objetar que não vale a pena tanto esforço, tomarei de empréstimo a sugestão de um amigo, que citava Italo Calvino que, por sua vez, citava alguém que citava Sócrates:

Enquanto era preparada a cicuta, Sócrates estava aprendendo uma ária com a flauta. 'Para que lhe servirá?', perguntaram-lhe. 'Para aprender esta ária antes de morrer'. (Calvino, 1998, p.16) 
POR UMA ÉTICA EM PROFISSÃO...

Referências

ALBERONI, F. A amizade. 3.ed. Rio de Janeiro: Rocco, 1993.

ALBERONI, F., VECA, S. O altruísmo e a moral. 2.ed. Rio de Janeiro: Rocco, 1992.

ARISTÓTELES. Ética a Nicômaco. In: Os pensadores. São Paulo: Nova Cultural, 1987. v.2.

CALVINO, I. Por que ler os clássicos. São Paulo: Companhia das Letras, 1998.

COMÊNIO, Didática magna. Lisboa: Fundação Calouste Gulbenkian, 1957.

CAMPS, V. Ética, retórica, política. 2.ed. Madrid: Alianza Editorial, 1995.

CAMPS, V. Virtudes públicas. Madrid: Espasa Calpe, 1996.

ENCICLOPÉDIA ou dicionário raciocinado das ciências, das artes e dos ofícios por uma sociedade de letrados. São Paulo: UNESP, 1989.

FOUCAULT, M. Vigiar e punir. São Paulo: Paz e Terra, 1991.

GUSDORF, G. Professores para quê? Lisboa: Moraes, 1970.

HAMELINE, D. O educador e a acção sensata. In: NÓVOA, A. Profissão professor. Porto: Porto

Editora, 1991. p.33-60.

HANNOUN, H. Educação: certezas e apostas. São Paulo: UNESP, 1998.

INTERFACE - comunicação, saúde, educação. Botucatu: Fundação UNI, v.1, n.1,1997.

JAEGER, W. Paideia: a formação do homem grego. São Paulo: Martins Fontes, 1995.

LARROSA, J. Pedagogia profana: danças, piruetas e mascaradas. Porto Alegre: Contrabando, 1998.

MANNHEIM, K. Ideologia e utopia. Rio de Janeiro: Guanabara, 1986.

MORIN, L. Os charlatães da nova pedagogia. Mira-Sintra: Europa-América, 1976.

NAGLE, J. Introdução ao estudo da educação. Araraquara: Departamento de Educação da Faculdade

de Filosofia, Ciências e Letras de Araraquara/UNESP, 1976. (mimeogr.)

NÓVOA, A. (Org.) Profissão professor. Porto: Porto Editora, 1991.

SNYDERS, G. Alunos felizes: reflexão sobre a alegria na escola a partir de textos literários. 2.ed. São

Paulo: Paz e Terra, 1996

BOTO, C. Por una ética en la profesión: rumbo a una nueva paideia, Interface _ Comunic, Saúde, Educ, v.6, n.10, p.9-26, 2002.

El presente artículo intenta discutir la actualidad del concepto de paideia, a la luz del entrelazamiento entre el original referente griego y la categoría operatoria de lo que aquí denominamos una "ética en la profesión". Se trata de un estudio que busca formular algunas directrices para pensar el tema de la enseñanza y del aprendizaje, partiendo metodológicamente de la acepción de interdisciplinaridad. Así, se podrá, huyendo de las especializaciones fragmentarias del campo, recomponer el arte del pensamiento pedagógico, incluyendo en él sus aspectos éticos esenciales. De este modo, creemos posible establecer, para los profesores y estudiantes de este tercer milenio, una nueva y moderna paideia.

PALABRAS CLAVE: Paideia; Educación; ética profesional; aprendizaje; enseñanza. 